\title{
THE SPINAL NEEDLE AS A CARRIER OF FOREIGN MATERIAL
}

\author{
Victor Brandus, M.D. *
}

UNDER tHE SUggestive TITLE "Coring: The Unseen Menace," Charlebois ${ }^{1}$ recently published an exhaustive study on the mechanics of coring. A core is that particle of a pliable membrane, such as skin or rubber, which is cut away by a hollow needle upon its insertion through the membrane. This "needle biopsy" remains hidden in the lumen of the needle and usually passes unrecognized.

Recently, in response to a sudden increase in the incidence of "postspinal" headache in the hospital with which I had been associated, I examined under the microscope a number of spinal needles in current use. The results of this investigation are here presented and discussed.

\section{Method and Findings}

A total of sixty 22-gauge needles with stylet were examined under the microscope at $\times 30$ or $\times 60$ power. These were divided in three categories of 20 needles each. In the first category were sterile needles ready for use as found on the specially arranged spinal trays. In 30 per cent of these, various materials tentatively identified as blood corpuscles or pieces of tissue were noticeable between the stylet and the inner surface of the needle.

In the second category were the needles used in performing the spinal anaesthesia on surgical patients in the operating room. The punctures were performed without introducer and following an unsuccessful attempt the needle was discarded. All needles with which a successful tap had been performed were clean.

The third category consisted of needles which were introduced for a distance of one inch in the same patients as above but the stylet was not removed and anaesthetic solution was not injected. Seventy-five per cent of them carried foreign material fixed to their tips, identified as pieces of skin or threads of epidermis still covered with Betadine (Providone-iodine, Purdue Frederick Co.) used for the preparation of the field.

Analysing these findings we concluded that the needles from the first category were those which had been discarded following an unsuccessful tap and still carried foreign material in the same way as the needles from third category did (Fig. 1). The core was cut away by the heel of the needle, as shown by Charlebois, ${ }^{1}$ and filled that portion of the lumen between the maladjusted stylet and the wall. After removal of the stylet, the routine flushing of an apparently clean and otherwise patent needle by an unaware technician was not always successful in dislodging the dried core adhering to the wall. The lack of foreign material in the needles from the second category was due probably to the fact that the freshly cut core was washed by the spinal fluid during the test aspiration,

-Anesthesiology Service, Beth Israel Medical Center, New York, N.Y. 


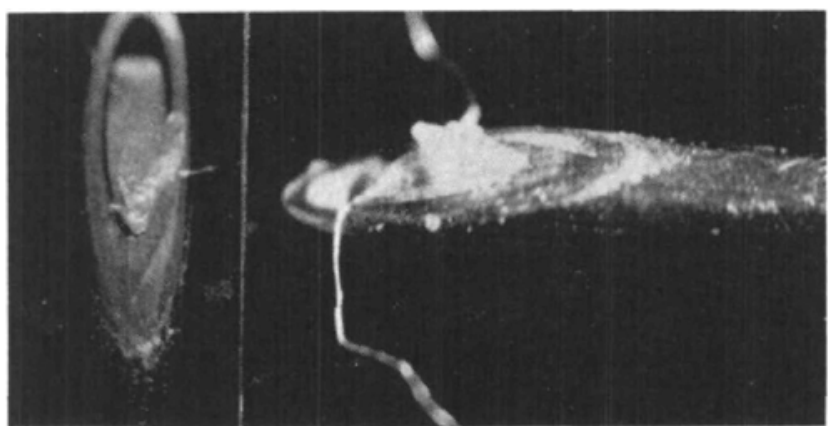

Figure 1, Bevel of spinal needle containing a core of skin.

because, quite often, small particles visible with the naked eye were noticed floating in the previously clear anaesthetic solution.

\section{Discussion}

In 1944, Dickson ${ }^{2}$ mentioned that "certain findings [are] not usually recorded in the official description of the cerebrospinal fluid . . . squamous cells from the skin surface together with their accompanying staphylococci . . . occasionally even a little cylindrical fragment of skin punched out by the exploring needle . . . myelocytes accompanied by nucleated red corpuscles from the bone marrow due evidently to the over-enthusiastic penetration of one of the vertebral bodies."

In 1950, Magath and McClellan, ${ }^{3}$ puncturing with hollow needles through rubber stoppers covering drug vials, "cored out" plugs in a proportion of 60-70 per cent. To prevent plugging they recommended a darning-point needle with lateral openings.

In 1955, Crawford Little, ${ }^{4}$ performing pneumothorax with 18-gauge hollow needles which were inspected macroscopically before and after use, found fragments of skin in the end of the needle on withdrawal from the body "in a proportion varying from 25 to 50 per cent with the individual physician." The area of the skin was about twice that of the cross-section of the needle. In trocharended or side-opening needles, no particles were found.

In 1958 Gibson and Norris, ${ }^{5}$ in a series of experiments, performed 300 tests with 18- to 24-gauge hollow needles thrust through the skin. Only fragments large enough to be identified by the naked eye were accepted as positive results. Overall frequency of punched-out fragments was 69 per cent. Some needles removed fragments at each thrust, others only sporadically. The incidence with needles of different sizes showed no significant variations. Needles with stylet or with side openings did not remove skin fragments. No significant variations were noted between new and re-sharpened needles. They were able to produce dermoid cysts in rats by subcutaneous injection of small fragments of skin.

In 1966, Charlebois, ${ }^{1}$ in the study mentioned above, commenting on the possibility of septic contamination or dermoid cyst formation due to these "fullthickness skin grafts" carried by the needle states that in his experiments the 
18-gauge needle with pointed end produced skin cores in 85 per cent of cases, the 17-gauge Tuohy side-opening needle without stylet 75 per cent, and with stylet 87 per cent. The size of the cores varied according to the fit of the stylet and the gauge of the needle.

Relatively numerous cases of intraspinal lumbar epidermoid tumours (cholesteatomas) are reported in the literature after $1956 .{ }^{6-9}$ All cases reported have in common a history of meningitis, more often of tuberculous origin, treated five to ten years previously with lumbar taps and intrathecal injections of streptomycin, varying from two to sixty in number. Blockey ${ }^{10}$ states, "The extreme rarity of epidermoid tumours of congenital origin contrasts sharply with these findings. . . . This contrast suggests the etiological significance of lumbar puncture. ... There can be little doubt that in our series and in the larger series of Economos, the epidermoid tumours had been growing from epidermal cells implanted during lumbar puncture."

Grave, diffuse, neurological complications attributable to spinal anaesthesia, such as myelopathies, arachnoiditis, meningo-encephalitis, and septic or aseptic meningitis, were reviewed by Kennedy et al. ${ }^{11}$ in 1950 . Among the cases reported by them, case \#l is that of a patient whose skin was prepared with Merthiolate ${ }^{\circledR}$ (thimerosal, Lilly), to which she was allergic. Postoperatively she developed a localized allergic cutaneous reaction concomitantly with neurological disorders which resulted eventually in permanent paraplegia. Whether or not the two complications were related remains a matter of speculation and concern. However, after 1950 the grave neurological sequelae are conspicuously absent from the large surveys, ${ }^{12-14}$ with the exception of one case of septic meningitis reported by Sadove. ${ }^{15}$

Spinal headaches of long duration or accompanied by meningismus ${ }^{16}$ still occur in anaesthetic practice. Statistically the incidence of headache, a common symptom in a variety of neurological disorders when the spinal needle is instrumental in its aetiology, bears a direct relationship to the gauge of the needle employed, the shape of its point, and the use or non-use of an introducer.

In order to avoid the comparison of "incomparable" figures, obtained from different techniques and given different interpretations, the data of each investigator for a given needle will be compared with his own data while using a different needle, and the results, expressed percentage-wise, will be evaluated.

Using the figures of Dripps and Vandam ${ }^{12,13}$ as a standard for the conventional bevel needle, the incidence of spinal headache is 14,9, or 6 per cent for the 20-, 22-, and 24-gauge needles respectively. It is also apparent that from 20-gauge down to 24-gauge, the incidence of headache decreases linearly and parallel with the gauge of the needle, decreasing by 33 per cent of the higher value between two alternate numbers.

The use of the pencil-point needle did not spread much in the medical profession, and the pertinent data is scarce. Hart and Whitacre, ${ }^{17}$ comparing a 20 -gauge short-bevel with an identical size pencil-point needle, give the incidence of 5 per cent and 2 per cent respectively, or a decrease of 60 per cent. Cappe, ${ }^{18}$ using a 19-gauge conventional bevel and a 20-gauge pencil-point, found an incidence of 22 per cent and 6.6 per cent respectively, or a decrease of 70 per cent. 
An "introducer" may be used "to act as a brace or splint for the needle," as Sise $^{19}$ devised it, or to prevent the spinal needle from making contact with the skin. To be efficient for the latter purpose, it must have a stylet in order to avoid being plugged by skin. The comparative data of Greene, ${ }^{20}$ who used an introducer with stylet, show an incidence of 10 per cent for a 22-gauge needle without introducer and 2 per cent and 0.4 per cent for 24- and 26-gauge needles with introducer, the percentage drop being 80 and 96 per cent respectively, a decrease significantly greater than would be expected from the figures of Dripps and Vandam for the conventional needles used without introducer.

\section{SummaRY ANd Conclúsions}

When used in performing a spinal tap, the conventional 22-gauge spinal needle produces cores of skin or threads of epidermis in 75 per cent of cases. Most of the fresh cores are sucked into the syringe during the test aspiration of the spinal fluid, and some of them may be re-injected into the subarachnoid space with the potential hazards of septic or chemical contamination.

When the available clinical surveys are analyzed in the light of these facts, the incidence of postspinal headache appears to be related not only to the gauge of the needle but also to its capacity for coring, and this possible aetiology is presented as an alternate hypothesis.

\section{RÉSUMÉ}

Lorsqu'on procède a une ponction spinale, dans 75 pour cent des cas, l'aiguille ordinaire de calibre 22 produit des bouchons de peau ou des filaments d'épiderme. La plupart des bouchons frais sont attirés dans la seringue lorsqu'on aspire du liquide céphalorachidien, et quelques uns peuvent être réinjectés dans l'espace sous-arachnoïdien, ce qui risque d'engendrer une contamination septique ou chimique.

A la lumière de ces faits, en analysant les études cliniques dont on dispose, il semble que la céphalée post-rachidienne soit en rapport non seulement avec le calibre de l'aiguille mais aussi avec son pouvoir de produire un bouchon, et cette étiologie possible est présentée comme une hypothèse plausible.

\section{REFERENCES}

1. Chartebois, P. A. Coring: The Unseen Menace. Canad. Anaesth. Soc. J. 13: 585 (1966).

2. Drckson, W. E. C. The Cerebrospinal Fluid in Meningitis. Arch. Neuro. Psychiat. 20: 69 (1944).

3. Magath, T. B. \& McClellan, J. T. Reaction to Accidentally Injected Rubber Plugs. Am. J. Clin. Path. 20: 829 (1950).

4. Crawford Litrte, D. Skin Fragments in End-opening Needles. C.M.A.J. 72: 374 (1955)

5. Gimson, T. \& Norrus, W. Skin Fragments Removed by Injection Needles. Lancet. ii: 983 (1958).

6. Chonemis, C.; Economos, D.; Papadatos, C.; \& Gargoulas, A. Intraspinal Epidermoid 
Tumours (Cholesteatomas) in Patients Treated for Tuberculous Meningitis. Lancet. ii: 437 (1956).

7. Economos, D. \& Caracalos, T. Cholesteatomes intrachidiens multiples, complications tardive d'injections intrarachidiennes pour Meningite Tuburculouse de l'enfance. Rev. neurolog. 97: 81 (1957).

8. Gros, C. Intraspinal Epidermoid Cysts. Neurochir, 7: 163 (1961).

9. Castaigne, I. Cholesteatoma du cauda ecuina. Presse Med. 70: 2211 (1962).

10. Blockey, N. J. \& Schonstein, J. Intraspinal Dermoid Tumors in the Lumbar Region of Children. J. Bone and Joint Surg. 43B: 556 (1961).

11. Kennedy, F.; Efrron, A. S.; \& Perry, G. The Grave Spinal Cord Paralysis Caused by Spinal Anesthesia. Surg. Gynaec. \& Obs. 91: 385 (1950).

12. Vandam, L. D. \& Dripps, R. D. A Long-Term Follow-up of 10,098 Spinal Anesthetics. Surgery. 38: 436 (1955).

13. - Long-Term Follow-up of Patients Who Received 10,098 Spinal Anesthetics. J.A.M.A. 161: 586 (1956).

14. Emner, H. An Evaluation of Spinal Anesthesia in Obstetrics. Anesth. \& Analg. 38: 378 (1959).

15. Sadove, M. S.; Levin, M. J.; \& Rant-Semdanaj, J. Neurological Complications of Spinal Anesthesia. Canad. Anaesth. Soc. J. 8: 405 (1961).

16. Harris, L. M. \& Harmed, M. H. The Comparative Incidence of Post-lumbar Puncture Headache Following Spinal Anesthesia Administered through 20 and 24 Gauge Needles. Anesthesiology. 14: 390 (1953).

17. Hart, J. R. \& Whitacre, R. J. Pencil-point Needle in Prevention of Post-spinal Headache. J.A.M.A. 147: 657 (1952).

18. CAPpE, B. E. \& DEUTSCH, E. V. A Maleable Cone-tip Needle for Fractional Spinal Anesthesiology. 14: 398 (1953).

19. Sise, L. F. Lumbar Puncture Technique. Am. J. Surg. 5: 577 (1928).

20. GreEne, B. A. A 26-Gauge Lumbar Puncture Needle. Anesthesiology. 11: 464 (1950). 